\title{
PERBEDAAN WAKTU AWAL PEMBERIAN LARVA IKAN SEBAGAI PAKAN DALAM PEMELIHARAAN LARVA IKAN TUNA SIRIP KUNING Thunnus albacares
}

\author{
Gunawan $^{\mathrm{a}^{*}}$, Jhon Harianto Hutapea ${ }^{\mathrm{a}}$ \\ ${ }^{a}$ Balai Besar Riset Budidaya Laut dan Penyuluhan Perikanan, Banjar Dinas Gondol, Desa Penyabangan, \\ Kecamatan Gerokgak, Kabupaten Buleleng, Bali-Indonesia \\ *Koresponden penulis : gunawan9505@gmail.com
}

\begin{abstract}
Abstrak
Salah satu penyebab kematian larva ikan tuna pada stadia awal adalah sifat larva ikan tuna yang beralih dari sifat planktivorus ke piscivorus dalam stadia larva, dimana untuk mempertahankan hidup dan pertumbuhannya harus terdapat larva ikan sebagai ransum pakan. Penelitian ini bertujuan untuk menentukan waktu yang tepat untuk memulai pemberian pakan berupa larva ikan yang baru menetas pada pemeliharaan larva ikan tuna sirip kuning. Penelitian dilaksanakan di hatcheri ikan tuna dan laboratorium Balai Besar Riset Budidaya Laut dan Penyuluhan Perikanan (BBRBLPP), Gondol. Telur ikan tuna ditebar dalam bak beton ukuran 3x2x1 m (volume $6 \mathrm{~m}^{3}$ ) dengan kepadatan 100.000 butir/bak. Perlakuan yang diujicobakan adalah waktu awal pemberian larva ikan tuna yang baru menetas sebagai pakan untuk larva ikan tuna sirip kuning dengan tiga perlakuan dan tiga ulangan : A. Mulai umur tujuh hari; B. Mulai umur sembilan hari, dan C. Mulai umur sebelas hari. Pengambilan gambar larva dengan menggunakan program ACT-1 dan analisa data dengan ANOVA. Dari ketiga perlakuan dalam penelitian ini diperoleh hasil bahwa perlakuan A menghasilkan pertumbuhan dan sintasan benih yang lebih tinggi dibandingkan perlakuan B dan C. Tetapi dari analisa statistik menunjukan tidak beda nyata dari semua perlakuan. Pemberian pakan larva tuna yang baru menetas pada perlakuan A dapat mengurangi kematian larva yang terjadi pada larva stadia awal, tetapi tidak dapat mengurangi kematian larva setelah umur limabelas hari sampai menjadi juvenil.
\end{abstract}

Kata kunci: ikan tuna sirip kuning, larva, Thunnus albacares, pakan awal, waktu pemberian pakan

\begin{abstract}
Main cause of tuna larvae mortality at early stadia is when feeding mode of larvae switches from planktivorous to piscivorous. Piscivorous mode is a stage when larvae need fish larvae as feed in order to survive and promote fast growth. The aim of research was to find the best timing for starting feeding tuna larvae with fish larvae. The research was conducted in tuna hatchery and laboratory of Institute for Mariculture Research and Fisheries Extension (IMRAFE), Gondol. Tuna eggs are stocked in 9 concrete tanks each with dimension of $3 \times 2 \times 1 \mathrm{~m}^{3}$ and stock 100,000 eggs/tank. The experimental design was completely randomized design with three treatments of different initial time supplied newly hatch fish larvae as feed for yellow fin tuna larva.: A. starting at seven days; B. starting at nine days, and C. Starting at eleven days. Larval were measured using ACT-1 program and then data were analysis with ANOVA. At the end of the research was found that treatment A giving higher growth and survival rate compared to treatments B and C but statistically was no significant difference. Actually, tuna larvae in treatment A, which feeding with newly hatched fish larvae earlier can reduce the mortality of larvae at early stadia, but when tuna larvae reach about fifteen days old, high cannibalism was again increased mortality of the larvae and continued until it becomes juvenile.
\end{abstract}

Keywords: Yellowfin tuna, larvae, Thunnus albacares, early feed, feeding time

\section{PENDAHULUAN}

Larangan terkait eksploitasi tuna dan pembatasan daerah tangkapan serta permintaan untuk meningkatkan pertumbuhan tuna, mendorong para peneliti untuk mengembangkan teknik budidaya tuna. Ikan tuna sirip kuning merupakan ikan yang sangat potensial untuk dibudidayakan, karena jenis ikan ini dapat memijah sepanjang tahun di perairan beriklim tropis [1,2]. Upaya pengembangan budidaya tuna sudah dilakukan di beberapa negara, namun rendahnya kelangsungan hidup larva ikan tuna 
untuk mencapai juvenil bagi sebagian besar spesies tuna yang dibudidaya menjadi kendala bagi ketersediaan benih ikan tuna untuk dibesarkan dalam karamba jaring apung. Kelangsungan hidup larva sebagian besar spesies ikan tuna untuk mencapai juvenil masih rendah, kematian terutama pada 10 hari pertama pemeliharaan larva. Fase ini sangat kritis, peningkatan mortalitas seringkali terjadi selama stadia tersebut $[3,4]$.

Kendala dalam pemeliharaan larva ikan tuna adalah mortalitas yang tinggi dapat dibagi atas tiga faktor utama. Yang pertama, tingginya mortalitas pada sepuluh hari pertama yang disebabkan oleh kualitas telur, nutrisi pakan dan faktor lingkungan seperti cahaya, arus dan kandungan oksigen, ammoniak dan nitrit dalam air serta tekanan osmosis media air pemeliharaan $[5,6]$. Bahkan diperkirakan bahwa ukuran pakan juga menentukan laju pertumbuhan. Larva ikan tuna pada 10 hari pertama tumbuh lambat lalu diikuti oleh laju pertumbuhan yang cepat, juga sering disebut sebagai stadia" large preyfast growth" dan ini berhubungan dengan ukuran pakan yang lebih besar [7]. Faktor kedua terjadi pada umur sekitar 20 hari yang disebabkan tingginya tingkat kanibalisme sesama larva [8]. Faktor ketiga adalah memasuki stadia juvenil dengan tingkat kemampuan renang yang sudah mendekati sempurna, sering terjadi kematian juvenil akibat menabrak dinding atau lompat keluar dari bak pemeliharaan [6].

Keberhasilan pengembangan sistem pencernaan sangat penting untuk kelangsungan hidup dan pertumbuhan larva ikan tuna [7]. Namun ternyata yang paling penting adalah sifat larva ikan tuna yang beralih dari planktivorus ke pisciforus dalam stadia larva, dimana untuk mempertahankan hidup dan pertumbuhannya harus terdapat larva ikan sebagai ransum pakan [8].

Hasil-hasil uji coba pemeliharaan larva di Balai di tahun 2015, menunjukkan terjadinya kematian larva stadia awal, umur diatas 10 hari dan mendekati metamorphosa ke juvenil [2] dan hal yang sama juga ditemui berbagai negara yang menekuni perbenihan ikan tuna $[7,9]$. Kematian pada stadia awal ini berhubungan dengan kualitas air atau berhubungan dengan tegangan permukaan air. Sedangkan setelah larva umur duabelas hari
(D-12) banyak kematian larva yang disebabkan oleh kanibalisme yang terjadi pada larva ikan tuna sirip kuning. Kanibalisme ini muncul karena sifat larva ikan tuna yang beralih dari planktivorus ke pisciforus dalam stadia larva, dimana untuk mempertahankan hidup dan pertumbuhannya harus terdapat larva ikan sebagai ransum pakan [8]. Bahkan ditemukan bahwa sintasan dan pertumbuhan larva ikan tuna sirip biru hanya dapat ditingkatkan jika larva ikan ditambahkan sebagai pakan [8].

Berdasarkan pertimbangan tersebut di atas, guna meningkatkan sintasan larva ikan tuna perlu dilakukan penelitian yang berkaitan dengan kapan waktu yang tepat memberikan pakan larva yang baru menetas sebagai pakan larva ikan tuna sirip kuning.

Tujuan dari penelitian ini adalah untuk menentukan waktu yang tepat untuk memulai pemberian pakan berupa larva ikan yang baru menetas pada pemeliharaan larva ikan tuna sirip kuning.

\section{METODE PENELITIAN}

\section{Tempat Penelitian}

Penelitian ini dilaksanakan di hatcheri ikan tuna dan laboratorium Balai Besar Riset Budidaya Laut dan Penyuluhan perikanan (BBRBLPP) Gondol, Kabupaten Buleleng Bali.

\section{Prosedur Penelitian}

Telur ikan tuna sirip kuning dari pemijahan alami induk di KJA ditebar dalam bak beton ukuran $3 \times 2 \times 1 \mathrm{~m}$ (volume $6 \mathrm{~m}^{3}$ ) sebanyak 9 bak dengan kepadatan 100.000 butir/bak. Di dalam bak pemeliharaan juga dilengkapi dengan sistem aerasi untuk meningkatkan kandungan oksigen pada air pemeliharaan larva, dan juga sistem pergantian air. Pemeliharaan hingga juvenil, managemen pakan pada pemeliharaan larva ikan tuna sirip kuning terlihat dalam Tabel 1. 
Tabel 1. Manajemen pakan pada pemeliharaan larva ikan tuna sirip kuning (Thunnus albacares)

\begin{tabular}{|c|c|}
\hline \multirow[t]{2}{*}{ Pakan } & Hari setelah menetas \\
\hline & $\begin{array}{lllllll}12 & 3 & 8 & 12 & 15 & 20 & 25\end{array}$ \\
\hline Nannochloropsis sp. & |----------------- \\
\hline Rotifer & $---\cdot$ \\
\hline Naupli copepod & ---- \\
\hline Larva bandeng & ----------- \\
\hline $\begin{array}{l}\text { Benih bandeng } \\
\text { (nener) }\end{array}$ & --- \\
\hline
\end{tabular}

Mulai dari larva menetas hingga umur empat hari ditambahkan minyak ikan pada permukaan air sebanyak 6 tetes dengan frekuensi dua kali sehari. Hal ini bertujuan agar lemak-lemak atau mucus yang dikeluarkan ketika larva menetas dapat terdorong menjauhi aerasi dan memeudahkan untuk pengambilan dengan beaker glass.

Fitoplankton dari jenis Nannochloropsis oculata diberikan ke dalam bak pemeliharaan saat larva berumur 2 hari sampai larva umur 17 hari (selama larva masih mengkonsumsi rotifer). Pakan alami berupa rotifer (Brachionus rotindiformis) diberikan pada larva umur dua hari (D-2) dengan kepadatan awal 10 ind./mL, dan naupli copepod diberikan pada larva umur 3 hari. Rotifer dalam bak dihitung dua kali sehari pagi dan sore, untuk dapat mengatur kepadatan yang diinginkan. Penambahan rotifer diberikan dua kali sehari pagi dan sore tergantung jumlah sisa di dalam tangki pemeliharaan. Waktu awal pemberian pakan sebagai perlakuan yaitu berupa larva ikan tuna yang baru menetas. Selanjutnya, larva bandeng yang baru menetas diberikan pada semua perlakuan setelah larva tuna berumur 13 hari, sejalan dengan peningkatan ukuran bukaan mulut larva ikan tuna. Benih bandeng (nener) diberikan pada larva D-16 sampai larva menjadi benih dan siap di panen. Pemberian pakan disesuaikan dengan kepadatan benih ikan tuna di dalam bak pemeliharaan.

Dalam pemeliharaan larva ikan tuna, air yang digunakan sudah melalui proses saringan berpasir. Proses ini bertujuan untuk menghilangkan partikel-partikel halus yang ada di air laut dan meminimalisir sumber penyakit yang ada di air laut. Selama pemeliharaan larva ikan tuna, kualitas air dijaga dalam kondisi optimal melalui manajemen sesuai Tabel 2.

Tabel 2. Managemen air, pembersihan dasar tangki dan pemberian minyak ikan pada pemeliharaan larva ikan tuna sirip kuning

\begin{tabular}{|c|c|}
\hline \multirow[t]{2}{*}{ Perlakuan } & Hari setelah menetas \\
\hline & $\begin{array}{llllllll}123 & 8 & 10 & 12 & 15 & 20 & 25\end{array}$ \\
\hline Minyak ikan & $\begin{array}{ll}------ \\
\end{array}$ \\
\hline $\begin{array}{l}\text { Pergantian air } \\
\text { Pembersihan } \\
\text { dasar bak }\end{array}$ & \\
\hline
\end{tabular}

Pergantian air mulai dilakukan saat larva berumur 5 hari (D-5) sebesar 5\% dan terus bertambah dengan semakin bertambahnya umur larva. Pembersihan dasar bak dilakukan setelah umur 18 hari, setelah larva berubah menjadi juvenil.

Perlakuan yang diujicobakan dalam penelitian ini adalah waktu awal pemberian larva ikan tuna yang baru menetas sebagai pakan untuk larva ikan tuna sirip kuning dengan Rancangan Acak Lengkap (RAL) tiga perlakuan dan tiga ulangan sebagai berikut:

A. Mulai umur tujuh hari saat larva mulai tumbuh gigi;

B. Mulai umur sembilan hari saat gigi larva sudah runcing, dan

C. Mulai umur sebelas hari sebelum sifat kanibal pada larva muncul

Larva ikan tuna yang baru menetas ini digunakan sebagai pakan awal karena ukuranya yang cukup kecil $(2,7-2,8 \mathrm{~mm})$ sangat sesuai dengan bukaan mulut larva tuna. Disamping itu ketersediaan larva tuna yang baru menetas setiap hari berasal dari pemijahan induk ikan tuna di KJA yang terjadi hampir setiap hari sepanjang tahun.

Parameter yang diamati meliputi pertumbuhan larva, jumlah dan jenis pakan dalam lambung larva, kelangsungan hidup larva pada akhir penelitian serta kualitas air meliputi : DO, salinitas, suhu, $\mathrm{pH}, \mathrm{NH}_{3}$, dan Nitrit serta total bakteri dalam media pemeliharaan.

\section{Analisis Data}

Sampel telur dan larva ikan tuna sirip kuning diamati dibawah mikroskop yang sudah terhubung dengan kamera dan komputer. Pengambilan gambar larva dengan 
menggunakan program ACT-1. Hasil dari pengambilan gambar dengan program ACT-1 selanjutnya diukur dengan menggunakan program WinRoof V-5.0 untuk mengetahui diameter telur dan oil globule ikan tuna sirip kuning, tingkat pertumbuhan larva (panjang total dan panjang standar). Data pertumbuhan yang diperoleh dilakukan analisis regresi antara laju pertumbuhan (panjang total dan panjang standar) dengan umur larva.

Untuk mengetahui rata-rata benih yang dihasilkan dan tingkat pertumbuhan terbaik pada akhir penelitian dari ketiga perlakuan dilakukan Uji statistik (ANOVA).

\section{HASIL DAN PEMBAHASAN}

\section{Hasil}

Hasil dari kegiatan penelitian yang telah dilakukan selengkapanya disajikan dalam Tabel 3.

Tabel 3. Hasil penelitian perbedaan waktu awal pemberian pakan dalam pemeliharaan ikan tuna sirip kuning

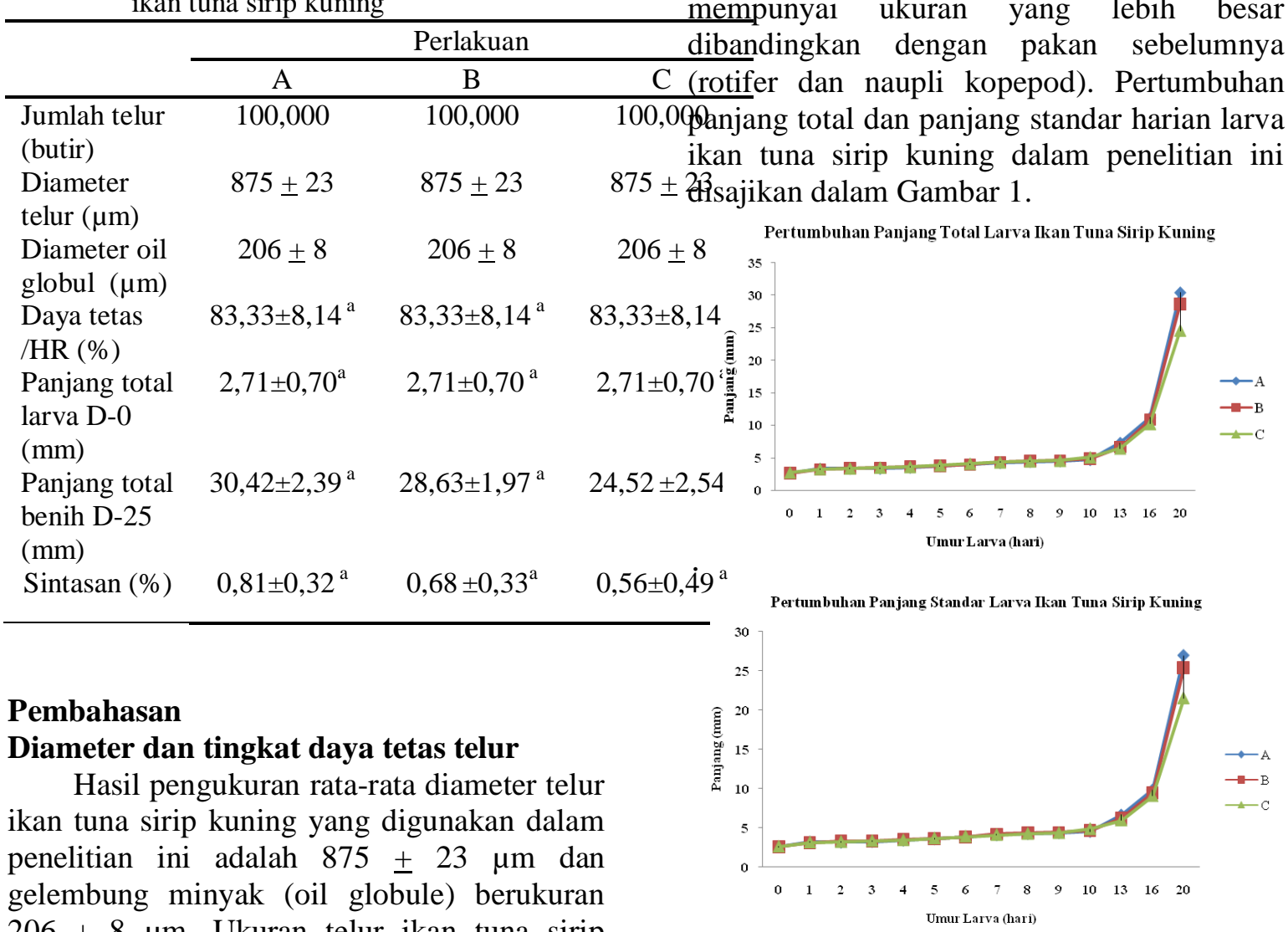

$206 \pm 8 \mu \mathrm{m}$. Ukuran telur ikan tuna sirip kuning dalam penelitian ini hampir sama dengan ukuran rata-rata diameter telur yang dipelihara dalam bak terkontrol berkisar

antara $880+15 \mu \mathrm{m}$ dan gelembung minyak $210 \pm 4 \mu \mathrm{m} \mathrm{[10]}$. Ukuran diameter telur dan oil globule ikan tuna sirip kuning dalam penelitian ini sedikit lebih kecil bila dibandingkan dengan ukuran diameter telur ikan tuna sirip kuning yang dipelihara pada hatcheri Inter-American Tropical Tuna Commission's Achotines Laboratory Panama dengan diameter telur $0,85-1,13 \mathrm{~mm}$ dan diameter oil globule $0,22 \mathrm{~mm}$ [4]. Penghitungan tingkat daya tetas (hatching rate) telur pada penelitian ini sebesar $83,33 \pm 8,14 \%$.

\section{Pertumbuhan larva}

Pertumbuhan larva ikan tuna sirip kuning dari ketiga perlakuan dalam penelitian ini terlihat bahwa pada awal pemeliharaan sangat lambat, tetapi petumbuhan larva ini meningkat sangat cepat setelah larva D-13. Pertumbuhan larva yang cukup cepat setelah D-13 ini disebabkan larva ikan tuna sirip kuning sudah mengkonsumsi larva ikan yang baru menetas (larva tuna dan larva bandeng) yang mempunyai ukuran yang lebih besar dibandingkan dengan pakan sebelumnya OQpanjang total dan panjang standar harian larva ikan tuna sirip kuning dalam penelitian ini

Gambar 1. Pertumbuhan panjang total dan panjang standar harian larva ikan tuna sirip kuning 
Larva ikan tuna sirip kuning saat baru menetas (D-0) dalam penelitian ini mempunyai panjang total tubuh $2,71 \pm 0,70$ $\mathrm{mm}$ dan panjang standar 2,68 $\pm 0,11 \mathrm{~mm}$. Larva ikan tuna pada D-0 dalam penelitian ini hampir sama dengan penelitian yang dilakukan pada tahun sebelumnya yang mempunyai panjang total tubuh $2,64 \pm 0,11$ $\mathrm{mm}$ dan panjang standar 2,56 $\pm 0,11 \mathrm{~mm}$ [11]. Tetapi ukuran panjang total larva ikan tuna sirip kuning pada D-0 ini lebih kecil bila dibandingkan dengan larva ikan tuna sirip biru atlantik (Thunnus thynnus) pada umur yang sama dengan panjang total tubuh 3,4 mm [12].

Tidak terdapat perbedaan pertumbuhan larva (panjang total dan panjang standar) yang signifikan dari ketiga perlakuan sampai larva berumur D-10. Perbedaan pertumbuhan mulai tampak saat larva D-13, dimana perlakuan A pertumbuhanya lebih cepat dibandingkan dengan perlakuan A dan B. Pada D-13 larva pada perlakuan $\mathrm{A}$ mempunyai panjang total tubuh 6,63 $\pm 0,32 \mathrm{~mm}$, perlakuan B 6,24 \pm $0,21 \mathrm{~mm}$, sedangkan pada perlakuan C 5,95 \pm $0,11 \mathrm{~mm}$. Perbedaan pertumbuhan panjang tubuh larva pada D-13 ini disebabkan karena pada sebagian besar larva pada perlakuan A dan B sudah mengkonsumsi larva ikan tuna yang baru menetas yang sudah terlebih dahulu diberikan dibandingkan pada perlakuan $\mathrm{C}$. Dari hasil pengamatan kandungan isi perut larva ikan tuna pada D-10 juga sudah diketahui adanya pakan berupa larva yang baru menetas pada sebagian besar larva ikan tuna pada perlakuan A dan sebagian kecil pada perlakuan B. Pertumbuhan larva ikan tuna pada perlakuan A ini terus lebih tinggi dibandingkan dengan perlakuan $\mathrm{B}$ dan $\mathrm{C}$ sampai akhir penelitian.

Tingkat pertumbuhan panjang total larva ikan tuna sirip kuning pada akhir penelitian (D-20) adalah pada perlakuan A panjang total $30,42 \pm 2,39 \mathrm{~mm}$, perlakuan B 28,63 $\pm 1,97 \mathrm{~mm}$, dan perlakuan $C$ sebesar 24,52 $\pm 2,54 \mathrm{~mm}$. Sedangkan panjang standar larva ikan tuna sirip kuning pada akhir penelitian pada perlakuan A sebesar 26,93 $\pm 2,78$, perlakuan B $25,36 \pm 2,16$ dan perlakuan $C 21,50 \pm 2,43$. Dari hasil pengukuran panjang total benih ikan tuna pada akhir penelitian ini menunjukan bahwa pemberian pakan awal berupa larva ikan tuna yang baru menetas yang diberikan pada saat larva berumur 7 hari (perlakuan A), memberikan pertumbuhan yang lebih tinggi bila dibandingkan dengan pemberian pakan berupa larva ikan tuna yang baru menetas pada D-9 (perlakuan B) dan D11 (perlakuan C). Tetapi dari analisa statistik dari ketiga perlakuan tingkat pertumbuhanya tidak beda nyata. Hal ini terjadi karena tingginya variasi ukuran antar individu dalam satu perlakuan.

Hasil penelitian ini menunjukan bahwa pertumbuhan larva ikan tuna sirip kuning pada akhir penelitian yang dipelihara dalam ketiga perlakuan ini masih lebih tinggi bila dibandingkan dengan penelitian yang dilakukan oleh [13] pada spesies yang sama dan umur yang sama yang dilakukan di Panama yang memilik panjang total tubuh sebesar 10,40 $\pm 0,70 \mathrm{~mm}$ dan panjang standar $9,30 \pm 0,60 \mathrm{~mm}$. Panjang total larva ikan tuna sirip kuning dari ketiga perlakuan penelitian ini juga lebih tinggi bila dibandingkan dengan panjang total tubuh larva ikan tuna sirip biru atlantik pada D-20 yang sebesar kurang lebih $17 \mathrm{~mm}[12]$.

Berdasarkan data perkembanganya dapat diketahui pertumbuhan panjang total larva ikan tuna sirip kuning pada ketiga perlakuan mengikuti persamaan eksponensial, pada perlakuan A dengan persamaan $\mathrm{y}=$ $2.310 \mathrm{e}^{0.101 x}\left(\mathrm{R}^{2}=0.873\right)$, perlakuan $\mathrm{B}$ dengan persamaan $\mathrm{y}=2.360 \mathrm{e}^{0.098 \mathrm{x}}\left(\mathrm{R}^{2}=0.876\right)$, dan perlakuan $\mathrm{C}$ dengan persamaan $\mathrm{y}=$ $2.427 \mathrm{e}^{0.093 x}\left(\mathrm{R}^{2}=0.894\right)$ seperti terlihat dalam Gambar 2. 


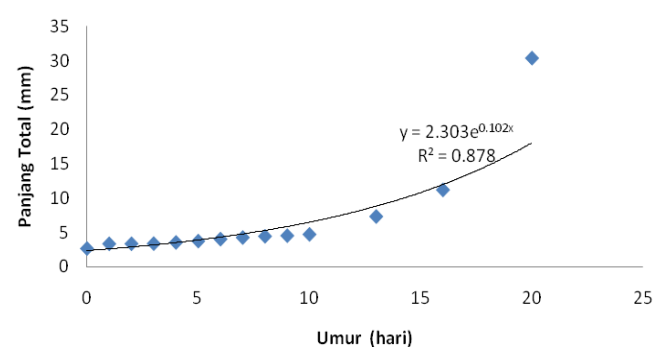

B

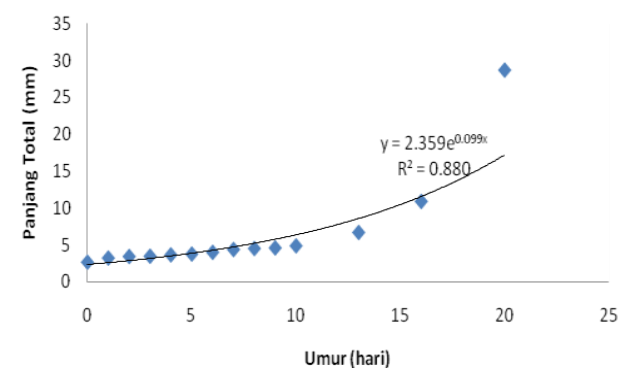

C

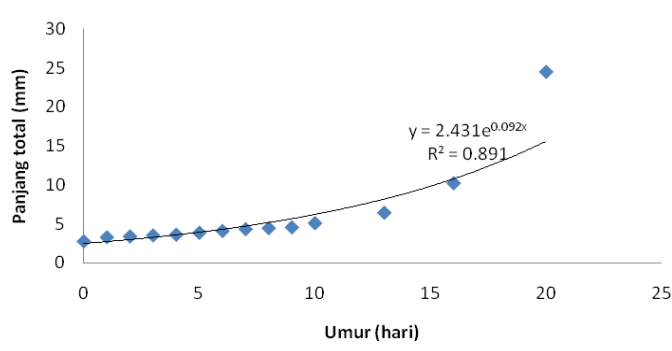

Gambar 2. Hubungan panjang total dengan umur larva ikan tuna sirip kuning dari ketiga perlakuan penelitian

Demikian juga dengan pertumbuhan panjang standar larva ikan tuna sirip kuning dari ketiga perlakuan dalam penelitian ini juga mengikuti persamaan eksponensial. Pada perlakuan A pertumbuhan panjang standar dengan persamaan $\mathrm{y}=2.263 \mathrm{e}^{0.096 \mathrm{x}}\left(\mathrm{R}^{2}=\right.$ 0.871), perlakuan $\mathrm{B}$ dengan persamaan $\mathrm{y}=$ $2.312 \mathrm{e}^{0.094 \mathrm{x}}\left(\mathrm{R}^{2}=0.875\right)$, dan perlakuan $\mathrm{C}$ dengan persamaan $\mathrm{y}=2.38 \mathrm{e}^{0.088 \mathrm{x}}\left(\mathrm{R}^{2}=0.895\right)$ seperti terlihat dalam Gambar 3.

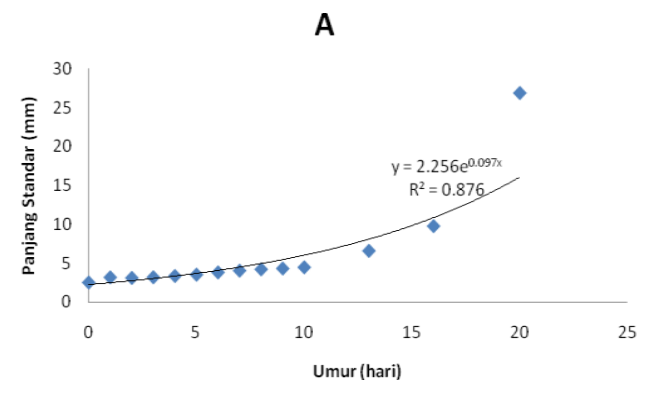

B

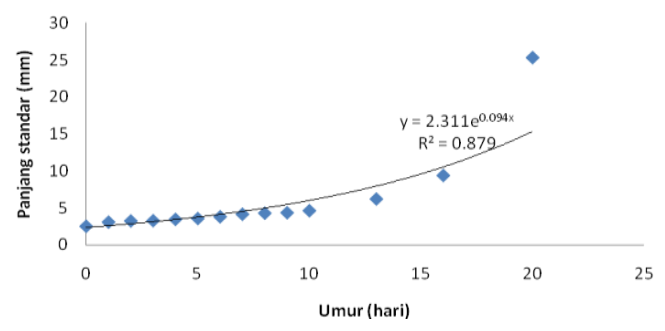

C

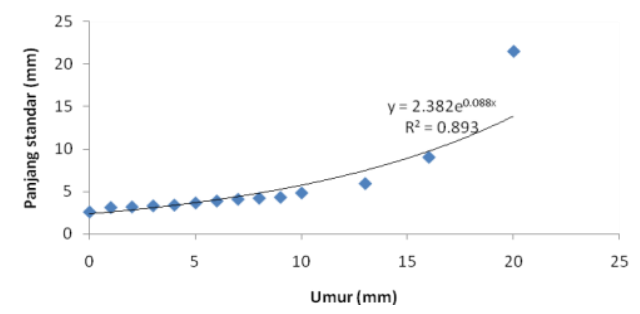

Gambar 3. Hubungan panjang standar dengan umur larva ikan tuna sirip kuning dari ketiga perlakuan penelitian

\section{Sintasan}

Benih ikan tuna pada akhir penelitian dipanen untuk dipindahkan dalam bak pendederan, dengan rata-rata sintasan yang dihasilkan pada perlakuan A sebesar $0,81 \pm 0,32 \%$, perlakuan B sebesar 0,68 $\pm 0,33$ $\%$, dan perlakuan $\mathrm{C}$ sebesar 0,56 $\pm 0,49 \%$. Sintasan benih yang dihasilkan dari perlakuan A lebih tinggi dibandingkan dengan perlakuan yang lain, tetapi dari analisa statistik menunjukan tidak beda nyata dari ketiga perlakuan karena nilai standar deviasinya yang tinggi.

Ssampai D-15 jumlah larva di dalam bak pada perlakuan A dan B lebih banyak bila dibandingkan pada perlakuan C. Tetapi saat larva mendekati perubahan menjadi juvenil sampai sudah menjadi juvenil banyak terjadi kematian yang disebabkan karena kanibal dan juga kematian karena menabrak dinding bak pemeliharaan. Pada perlakuan C larva sudah 
mulai berkurang setelah D-11 yang disebabkan kematian karena kanibal, dan terus terjadi sampai larva menjadi juvenil. Kanibal pada larva ikan tuna ini karena sifat larva ikan tuna yang beralih dari planktivorus ke pisciforus dalam stadia larva, dimana untuk mempertahankan hidup dan pertumbuhannya harus terdapat larva ikan sebagai ransum pakan. Kanibal pada larva dan juvenil ini terjadi bukan hanya karena adanya variasi ukuran, tetapi juga terjadi pada larva dan juvenil dengan ukuran yang sama. Larva atau juvenil yang berukuran lebih kecil akan dimakan oleh larva atau juvenil yang berukuran lebih besar, tetapi larva atau juvenil yang ukuranya relatif sama terjadi kematian karena digigit tetapi tidak di makan. Kematian karena menabrak dinding setelah larva menjadi juvenil, biasanya terjadi saat mengejar pakan berupa benih bandeng hidup yang diberikan sebagai pakan. Benih bandeng di dalam bak pemeliharaan larva ikan tuna ada kecenderungan berenang pada bagian pinggir bak. Pengalaman selama ini larva dan juvenil ikan tuna tidak mau mengkonsumsi pakan buatan atau pakan berupa benih yang sudah mati.

\section{Pengamatan isi perut}

Pemberian rotifer dan naupli copepod sebagai pakan awal larva ikan tuna sirip kuning terbukti efektif, hal ini diketahui setelah perut larva dipencet dan dilakukan pengamatan kandungan isi perut pada larva D3 sudah terdapat rotifer dan naupli copepod. Jumlah rotifer dan naupli copepod di dalam perut larva ikan tuna sirip kuning ini terus meningkat sejalan dengan pertambahan umur larva. Penurunan terjadi setelah larva ikan tuna sirip kuning mengkonsumsi larva yang baru menetas sebagai pakan. Pada perlakuan A dan B jumlah rotifer dalam perut larva mulai menurun setelah D-11, hal ini disebabkan larva sudah mulai mengkonsumsi pakan berupa larva ikan yang diberikan pada D-7 (perlakuan A), dan D-9 (perlakuan B), demikian juga dengan jumlah naupli copepod di dalam perut larva. Sedangkan pada perlakuan $\mathrm{C}$ jumlah rotifer di dalam perut larva mulai menurun setelah D-12, yaitu sehari setelah larva ikan tuna diberi pakan berupa larva ikan yang baru menetas. Dari hasil pengamatan isi perut juga diketahui bahwa larva mulai mengkonsumsi pakan larva yang baru menetas pada D-10, yaitu pada perlakuan A dan B. Jumlah rotifer dan naupli copepod di dalam perut larva ikan tuna sirip kuning dalam penelitian ini terlihat dalam Gambar 4.
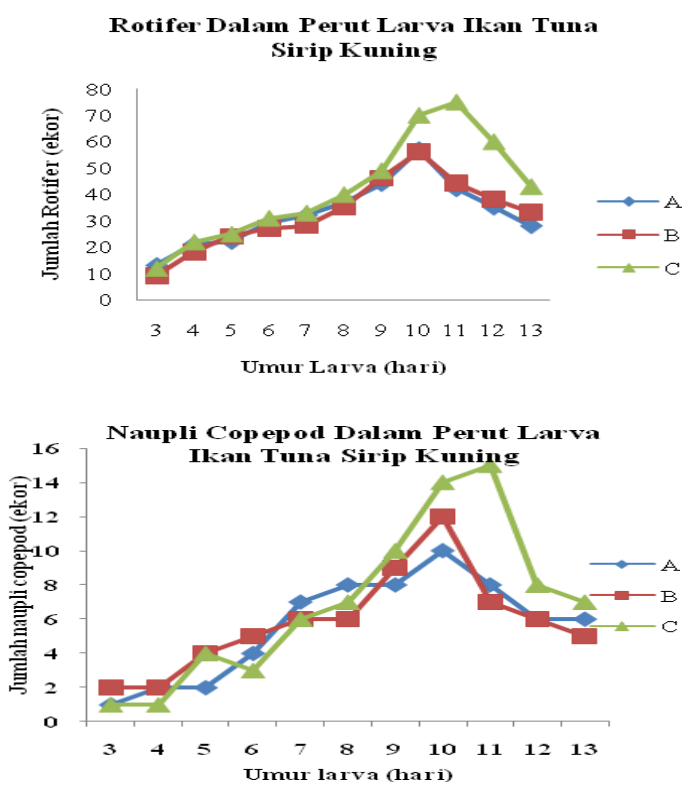

Gambar 4. Jumlah rotifer dan naupli copepod dalam perut larva ikan tuna

\section{Kualitas air}

Hasil pengukuran kualitas air dalam media pemeliharaan larva ikan tuna sirip kuning pada ketiga perlakuan disajikan dalam Tabel 4.

Tabel 4. Kualitas air penelitian perbedaan waktu awal pemberian pakan buatan dalam pemeliharaan ikan tuna sirip kuning

\begin{tabular}{lccc}
\hline \multirow{2}{*}{ Parameter } & \multicolumn{3}{c}{ Perlakuan } \\
\cline { 2 - 4 } & $\mathrm{A}$ & $\mathrm{B}$ & $\mathrm{C}$ \\
\hline Suhu $\left({ }^{\circ} \mathrm{C}\right)$ & $27,50-30,50$ & $27,50-30,50$ & $27,50-30,50$ \\
$\mathrm{pH}$ & $8,03-8,25$ & $8,07-8,26$ & $8,08-8,24$ \\
DO (mg/L) & $6,83-7,68$ & $6,79-7,56$ & $6,90-7,62$ \\
$\begin{array}{l}\text { Salinitas } \\
(\mathrm{ppt})\end{array}$ & $33-34$ & $33-34$ & $33-34$ \\
$\begin{array}{l}\text { Ammonia } \\
(\mathrm{mg} / \mathrm{L})\end{array}$ & $0,29-0,97$ & $0,34-0,86$ & $0,44-0,96$ \\
$\begin{array}{l}\text { Nitrit } \\
(\mathrm{mg} / \mathrm{L})\end{array}$ & $0,01-0,02$ & $0,01-0,02$ & $0,01-0,02$ \\
$\begin{array}{l}\text { Total bakteri } \\
(\mathrm{CFU} / \mathrm{mL}) \\
\left(\mathrm{x} 10^{3}\right)\end{array}$ & $0,58-1,48$ & $0,53-1,2$ & $0,58-1,21$ \\
\hline
\end{tabular}


Hasil pengukuran kualitas air pada semua perlakuan masih dalam batas normal kecuali kadar ammonia, dimana standar baku mutu suhu air laut untuk biota laut (budidaya perikanan) adalah $28-32{ }^{\circ} \mathrm{C}$ (alami), pH 78,5 , DO air laut untuk biota laut (budidaya perikanan) adalah $>5 \mathrm{mg} / \mathrm{L}$, salinitas 33-34 ppt dan standar baku mutu ammonia air laut untuk biota laut (budidaya perikanan) adalah $0,3 \mathrm{mg} / \mathrm{L}$, ambang batas kadar nitrit di perairan menurut adalah $0,05 \mathrm{mg} / \mathrm{L}$. Sedangkan kadar total bakteri dari hasil pengujian di laboratorium penguji BBRBLPP berkisar $0,53 \times 10^{3}-1,48 \times 10^{3} \mathrm{CFU} / \mathrm{mL}$ masih dalam kisaran batas normal, dimana total bakteri di perairan berkisar $10^{3}-10^{6}$ $\mathrm{CFU} / \mathrm{mL}$.

Suhu air tertinggi terjadi pada waktu siang hari pada saat larva umur 3 - 4 hari, dimana belum ada pergantian air pada bak pemeliharaan larva. Suhu air semakin stabil dengan bertambahnya umur larva seiiring dengan pergantian air yang semakin besar. Tingginya nilai DO dalam bak pemeliharaan ketiga perlakuaan ini dikarenakan oleh penambahan aerasi didalam bak dan juga sistem pergantian air (sirkulasi air) selama masa pemeliharaan larva. Nilai DO ini semakin tinggi saat larva memasuki stadia juvenil dikarenakan persentasi pergantian air yang semakin besar dan juga peningkatan kecepatan aerasi mulai larva memasuki stadia juvenil.

Kadar ammonia dalam air pemeliharaan larva ini melebihi batas normal. Sumber ammonia didalam air pemeliharaan larva ini berasal dari sisa pakan yang terbuang, dan juga dari pupuk yang terkandung dalam nannochlorosis sp. yang diberikan di dalam bak larva.

\section{KESIMPULAN}

Perlakuan A menghasilkan pertumbuhan yang lebih tinggi dibandingkan dengan perlakuan B dan C. Rata-rata jumlah benih yang dihasilkan pada akhir penelitian perlakuan A lebih tinggi dibandingkan dengan perlakuan B dan C. Data analisa statistik dari ketiga perlakuan tidak beda nyata dari semua perlakuan baik dari pertumbuhan maupun rata-rata jumlah benih yang dihasilkan pada akhir penelitian. Pemberian pakan larva tuna yang baru menetas saat larva umur tujuh hari (Perlakuan A) dapat mengurangi kematian larva yang terjadi pada larva D11-D15, tetapi tidak dapat mengurangi kematian larva setelah D-15 sampai menjadi juvenil.

\section{DAFTAR PUSTAKA}

[1] Andamari, R., J.H. Hutapea, dan B.I. Prisantoso. 2012. Aspek Reproduksi Ikan Tuna Sirip Kuning (Thunnus albacares). J. Ilmu dan Teknologi Kelautan Tropis, 4(1) : 89-96.

[2] Hutapea, J.H., A. Setiadi, Gunawan, dan I G. N. Permana. 2015. Kajian teknologi budidaya ikan tuna sirip kuning, Thunnus albacares di bak dan KJA. Laporan Teknis Akhir Kegiatan, Balai Besar Penelitian dan Pengembangan Budidaya Laut, Singaraja-Bali. 13 Hal.

[3] Patridge, G. 2009. The International Experience. In : Patridge, $\mathrm{G}$ (ed.). Hatchery Production of Yellowfin Tuna. International Specialised Skills Institute Inc. Melbourne-Australia. 11-25 pp.

[4] Buentello, J.A., C. Pohlenz, D. Margulies, V.P. Scholey, J.B. Wexler, D.T. Ramírez, W.H. Neill, P.H. Baltazar, and D.M. Gatlin, 2011. A preliminary study of digestive enzyme activities and amino acid composition of early juvenile yellowfin tuna (Thunnus albacares). J. Aquaculture, 312: 205211.

[5] Kaji, T. 1998. Bluefin Tuna larval rearing and development: State of the art. 84-89 pp. In : Bridges C.R. (ed.), García A. (ed.), Gordin H. (ed.). Domestication of the bluefin tuna Thunnus thynnus thynnus. Zaragoza : CIHEAM, 85-89 pp.

[6] Seoka, M., M. Kurata, and H. Kumai. 2007. Effect of docosahexaenoic acid enrichment in Artemia on growth of Pacific bluefin tuna Thunnus orientalis larvae. J. Aquaculture, 270 : 193-199.

[7] Kjorsvik, E., K. Pittman, and D.A. Pavlov. 2004. From fertilisation to the 
end of metamorphosis-functional development. In: Moksness, E., E. Kjorsvik, and Y. Olsen (Eds.), Culture of Cold-Water Marine Fish. Blackwell Publishing, Carlton, Victoria, 204-278 pp.

[8] Reglero, P., A. Ortega, E. Blanco, Ø. Fiksen, F.J. Viguri, F. De la Gándara, M. Seoka, and A. Folkvord. 2014. Sizerelated differences in growth and survival in piscivorous fish larvae fed different prey types. J. Aquaculture, 433 : 94-101.

[9] Nakagawa, Y., M. Eguchi, and S. Miyashita. 2007. Pacific bluefin tuna, Thunnus orientalis, larvae utilize energy and nutrients of microbial loop. $J$. Aquaculture, 267 : 83-93.

[10] Hutapea, J.H., G.N. Permana, dan R. Andamari. 2007. Perkembangan embrio ikan tuna sirip kuning (Thunnus albacares). J. Riset Akuakultur, 2(1): 914.

[11] Gunawan, J.H. Hutapea, dan A. Setiadi. 2016. Perkembangan morfologi dan pertumbuhan larva ikan tuna sirip kuning (Thunnus albacares) hasil budidaya. Dalam: Irianto, H.E. et al. (eds.). Prosiding Forum Inovasi Tekhnologi Akuakultur, Surabaya, 25-26 April 2016. Hlm. : 493-499.

[12] Yúferaa, M., J.B. Ortiz-Delgado, T. Hoffman, I. Siguero, B. Urup, and C. Sarasquete. 2014. Organogenesis of digestive system, visual system and other structures in Atlantic bluefintuna (Thunnus thynnus) larvae reared with copepods in mesocosm system. $J$. Aquaculture, 426-427: 126-137.

[13] Kobayashi, T., T. Honryo, Y. Agawa, Y. Sawada, I. Tapia, K.A. Macìas, A. Cano, V.P. Scholey, D. Margulies, and N. Yagishita. 2015. Gonadogenesis and slow proliferation of germ cells in juveniles of cultured yellowfin tuna, Thunnus albacares. J. Reproductive biology, 15: 106 - 112 . 